\title{
The role of digital technology in people-centered development: the basic needs approach in the Kampung Marketer Program
}

\author{
Sulasih $^{1^{*}}$; Agus Suroso $^{2}$; Weni Novandari ${ }^{3} ;$ Suliyanto $^{4}$ \\ ${ }^{1)}$ Faculty of Islamic Economics and Business, Universitas Islam Negeri Profesor Kiai \\ Haji Saifuddin Zuhri, Purwokerto, Indonesia \\ 1, 2), 3), 4) Department of Management, Faculty of Economics and Business, Jenderal \\ Soedirman University Purwokerto, Indonesia
}

*To whom correspondence should be addressed.Email: sulasihs@gmail.com

\begin{tabular}{|l|l|l|l|l|}
\hline DOI: & Received: & Revised: & Accepted: & Published: \\
10.22437/ppd.v9i6.15340 & 03.11 .2021 & 08.02 .2022 & 20.02 .2022 & 28.02 .2022 \\
\hline
\end{tabular}

\begin{abstract}
The Kampung Marketer program is a youth empowerment program specializing in digital marketing. The basic needs approach is used to evaluate community development. This approach states that it is necessary to have greater job opportunities, increase economic growth, and guarantee the community's basic needs for a better quality of life. This research aims to determine how digital roles are implemented in people-centered development and measure its impact with the basic needs approach. A qualitative approach uses a triangulation model that combines in-depth interviews, observations, and documents from Kampung Marketers. From the research results, it was found that digital resources aided people-centered development by increasing employment opportunities. In the 18 existing branches, the Kampung Marketer Program has accumulated 700 customer service and advertising skills. As a result of the program, the economic growth of communities with Kampung Marketer programs had increased, as indicated by the amount of income received by the empowered community of around IDR $1,000,000$ to IDR 3,000,000 and the total income that was distributed being 1.3 billion. It impacts meeting the basic needs of society and increasing the younger generation's enthusiasm for continuing their studies. The members of Kampung Marketer also could now pay for their children's tuition and even bought houses and land. The older generation who did not have technological skills were also supported and empowered by the program by establishing a business called "Saung Makaryo." They were trained to produce goods in their respective homes, and Kampung Marketers marketed them.
\end{abstract}

Keywords: Digital technology, Kampung Marketer, People-centered development

JEL Classification: O14, O33, O35

\section{INTRODUCTION}

Kampung Marketer exists because of the problem of a large number of unemployed, village youths migration or urbanization, the lack of employment opportunities in the village, the lack of young entrepreneurs in the village, and the lack 
of competence or skills of the villagers as well as the potential of human resources. Kampung Marketer is a village that empowers the community in digital marketing technology. Kampung Marketer has the vision to realize and increase people's income and build villages through technology. Companies need a lot of human resources who have competence in technology. Moreover, during the pandemic, all elements of the business community using online media, one of the elements of technology, in carrying out activities. Kampung Marketer is also an organization that trains and educates people about technology and further empowers people who already have the skills and expertise in digital marketing technology. The following are some of the awards received related to the programs carried out by Kampung Marketer:

Table 1. List of awards obtained by Kampung Marketer:

1. Winner of 2018 Liputan 6 Awards SCTV in Innovation Category.

2. Winner of the 2018 Central Java Province Pioneer Youth Education Sector.

3. Winner of the 2018 NET TV Independent Young Entrepreneur.

4. The Favorite Winner of Independent Young Entrepreneurs in 2018.

5. Runner-up Driving Youth from the Ministry of Youth and Sports Affairs.

6. Winner of the 2019 Sustainable Development Goals - Pemuda Indonesia Penggerak Perubahan (SDG PIPE)

Source : Kampung Marketer

Community development through an empowerment approach is People-Centered Development. This development is a planned and directed effort to improve the community's welfare (Suherman, 2017). This effort is made in ways that follow the basic principles of participation and justice. The results must apply to human survival (Sjahrir, 1988) states that the concept of People-Centered Development views creative initiatives from the people as the prime development resource and as a goal material and spiritual welfare.

Therefore, we formulate three approaches in evaluating community development, namely The Basic Need Approach, which consists: (1) creating job opportunities; (2) increasing economic growth; (3) fulfilling the basic needs of the community. Then this approach expands to include several elements of non-material basic needs for measuring the quality of life of community groups below the poverty line (Nasdian, 2015). Policy Implications of the Basic Needs Approach suggested that this approach be applied comprehensively and involve people in rural and informal sectors by developing the community's potential, trust, and ability to organize themselves and build according to the desired goals (Soedjatmoko, 1979).

Previous research related to community empowerment conducted by Suaedi \& Hariani (2018), Sari et al. (2020), Simamora (2020), Fianingsih (2020), Chasanah (2021), Muafani (2021) shows that the use of technology is significant in community empowerment activities for all sectors and the digital economy. Community empowerment also contributes to creating skilled human resources in digital technology. In addition, community empowerment has a positive impact on the socioeconomic conditions of the community. In different contexts and sectors of community empowerment, it shows that there is no need for a person who has knowledge and thoughts of the community to empower the community. The community is enough to be the subject of public activities that can affect the community in it. Based on the research, we can see that community empowerment which is part of community 
development, has a significant role in the output of human resources and institutions. Therefore, community empowerment must continue to be developed and applied in various sectors to support government programs for better community development. However, most of them only evaluate community empowerment dimensions from previous research. In contrast, it is still rarely studied related to community development and empowerment through people-centered development by evaluating it using the basic needs approach, so this is a gap in this research.

Based on the previous research gap and problems as stated above, the purpose of this research is to know the role of digital technology in people-centered development: the basic need approach in Kampung Marketer?

\section{METHODS}

Field research with a qualitative approach was conducted where the researcher went to visit the Kampung Marketer program in Purbalingga. According to Bogdan \& Taylor (1975), the qualitative method is a research procedure that produces descriptive data that contains spoken or written words by the subjects and observed behaviors. Qualitative research emphasizes the understanding of problems in social life based on a comprehensive, complex, and detailed level (Moleong, 2012). Moreover, qualitative research does not use the term population and sample but social situations and informants (Sugiyono, 2005). The informants in this study were the administrators of Kampung Marketer in Purbalingga.

This study used both primary and secondary data. Primary data were obtained directly from the informants of the Kampung Marketer program in Purbalingga. In contrast, secondary data were obtained indirectly through the program's documentation, the official media accounts of Kampung Marketer, and previous research. Data were collected through systematic observation and recording of the phenomena studied. Primary data were also collected through structured or unstructured interviews done face-to-face or by telephone. Different forms of documentation that recorded past events were also collected in writing, pictures, and monumental works (Sugiyono, 2011).

The data analysis techniques used in this research were data reduction, data presentation, drawing conclusions, and verifications. Data reduction was conducted through summarizing, selecting, and focusing on important aspects of data. This was done to provide a clear picture of the findings and help the researchers to collect more data. Then, data was presented in narrative text or short descriptions charts, and the relationships between categories were shown. The last step was concluding and conducting verifications based on valid and consistent evidence (Sugiyono, 2005). To test the validity of the data, triangulation was used by checking the data against multiple sources (Sugiyono, 2011). The data will be analyzed using descriptive statistics presented in a percentage chart.

\section{RESULTS AND DISCUSSION}

People-Centered Development or Community Development is a movement designed to promote better living for the whole community with active participation and, if possible, on the community's initiative. It includes the whole range of development activities undertaken by government or unofficial bodies in the district. Community development must use the cooperative movement and be put into effect in the closest association with local government bodies (Brokensha \& Hodge, 1969). In 
addition, according to (Nasdian 2015), community development is a movement designed to promote better living for the whole community with active participation and on the initiative of the community. (Christenson et al., 1980) in (Nasdian 2015) states that community development is a group of people working together in a community setting on a shared decision to initiate a process to change their economic, social, cultural, or environmental situation.

The community development must be launched to improve the standard of living of society as a whole (holistic) through encouraging the community to play a more active role and also continuing to try to open up opportunities for community development carried out based on or born from the initiative of the community itself. In other words, community development must be a community movement that includes various community development work programs from the district level, whether driven by the local government or by non-governmental institutions. The understanding that community development is development born of community initiatives is further emphasized by Dunham (1958). His statement stated that community development is an organized effort to improve the conditions of community life and the capacity for community integration and self-direction. Community Development seeks to work primarily through the enlistment and organization of self-help and cooperative efforts on the part of the community's residents, but usually with technical assistance from government or voluntary organizations.

The paradigm of the community development approach can be narrowed into two camps (Nasdian, 2015). The first camp is Production Centered Development. At the same time, the second camp is People-Centered Development which consists of decentralization, participation, empowerment, preservation, social networking, territorial, local self-sufficiency, and sustainability. Community-oriented community development through the empowerment of digital marketing technology means that the community is empowered to market products online for Small and Medium Enterprises (SMEs) throughout Indonesia.

The concept of using digital technology in People-Centered Development evaluates the basic needs approach. The use of digital technology in the Kampung Marketer is reflected through a community empowerment program (Kampung Marketer, 2021).

Education or learning division. Provide education and training to residents who enter the Kampung Marketer to become skilled human resources in the field of digital technology in terms of online marketing. Education and training related to digital marketing knowledge, product research, copywriting, Instagram and Facebook ads, cash on delivery transactions, team building and KPI (Key Performance Indicators), and financial literacy. Some of the skills taught in Kampung Marketer will shape up against them into:

a. Customer Service, a skill to handle prospective buyers through chat applications using WhatsApp and Facebook applications so that they are expected to be able to convert potential buyers to become real buyers.

b. Advertisers, a skill in using digital media to create advertising strategies for product and service offerings to prospective buyers, including training to make interesting copywriting using Facebook, Instagram and Google ads media.

c. Social Media Admin, a skill in fully utilizing digital media in managing audience interactions and producing content.

d. Content Writer, a skill to produce interesting content on a blog or sales page. 
e. Social Media Admin, Order Admin, and Marketplace Admin are services from Commerce that focus on store optimization in marketplaces such as Shopee, Tokopedia, Bukalapak, Lazada, etc. Marketplace optimization is needed for those of you who want to scale up your business during increasingly fierce competition.

f. Input data is to record, manage, and input order or transaction data and other data.

g. Based on demand, providing competent human resources following the skills that business people need.

Empowerment division. The task of this division is to empower selected human resources who have gone through training under the guidance of the education team. Human resources empowered by Kampung Marketer can work in Advertising and Customer Service. Empowerment is carried out based on SME partnership requests through the administration division. Currently, the number of community members Kampung Marketer has empowered has increased every year. In 2017 there were 60 members to 481 members in 2018. The increase continued to 721 members in 2019 and 777 members in 2020.

The number of SMEs that have collaborated with the Kampung Marketer is 260. Kampung Marketer currently has 18 branches, and by 2020 it will become 21 offices spread across the Karangmoncol sub-district (Selyn, Staf of Kampung Marketer Empowerment, 2021). A total of 26 residents' houses are used for activities carried out by the Kampung Marketer. The turnover earned, which is distributed to talents, is 1.3 billion per month.

In general, community development practitioners and theorists indicate it through development variables and community development goals based on their approaches. According to (Korten \& Klauss, 1984), The Basic Needs Approach measures community development. The Basic Needs Approach is a measurement of the progress of community development as indicated by an approach from the theory of basic needs that emphasizes 3 (three) development goals, including created job opportunities, increased economic growth, and fulfilling the basic needs of the community. However, it was later expanded to meet non-material needs, which indicate the quality of life. Empowerment theory was also submitted by Zimmerman, M. A. (2000).

Created job opportunities. Most of the youth who joined Kampung Marketer was from the Senior High School or Vocational High School education level, amounting to $80 \%$. At the same time, the rest came from the Junior High School, Bachelor, and Diploma levels. This condition illustrates that Kampung Marketer has a very large contribution to creating jobs. Kampung Marketer trains young people so that they have expertise in technology. In addition, the role of Kampung Marketer is also suppressing the level of urbanization. Most of the human resources backgrounds empowered by the Kampung Marketer come from a factory background, and they choose to join the Kampung Marketer. This shows that the role and contribution of Kampung Marketer in creating employment opportunities has a significant impact on the surrounding community. On average, the number of talented human resources in Kampung Marketer has increased yearly. Besides that, it can also be seen from the number of partners who join the Kampung Marketer, which will automatically need more human resources.

Figure 1 shows that the average number of talented or members in Kampung Marketer has increased each year. Besides, that can also be seen from the number of partners who join the Kampung Marketer also has increased each year. A result shows 
that digital technology's role in people-centered development can create jobs and reduce unemployment. It is in accordance with Sari et al., 2020 which states that it could reduce the rate of urbanization. The fact is, digital technology can create job opportunities, Safira et al. (2019). Iyengar et al. (2017) in Enablers for digital empowerment in technology using interpretive structural modeling (ISM) and MICMAC analysis can job creation.

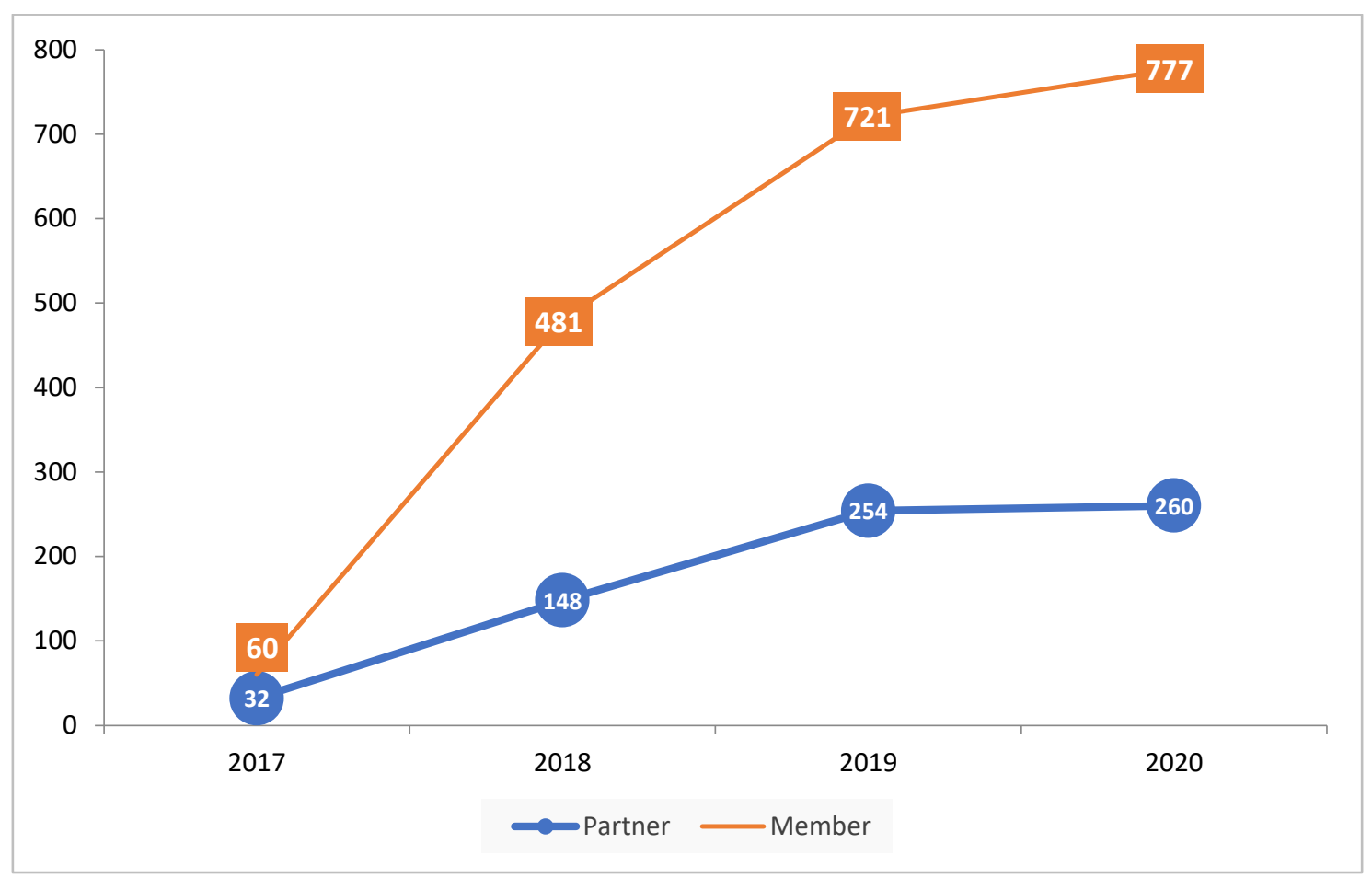

Figure 1. Number of talent (member) and partner of Kampung Marketer

Increased economic growth. The existence of Kampung Marketer agreed with the vision and mission of establishing. Kampung Marketer is expected to improve the community's welfare and advance the area. The total income distributed to empowered human resources reaches 1.3 billion in one month, with an average income of 1 million to 3 million per month. It depends on the performance, effort, and skills of the empowered human resources in their ability in online transactions. The more jobs produced by human resources, the more salaries and bonuses from business partners, in this case, SMEs, who utilize or empower human resources in Kampung Marketer. The increase in income received impacts reducing the level of urbanization. Young people choose to stay working in the village. This achievement agreed with Kampung Marketer's tag line or slogan, "Dari Desa Kita Berdaya," which means "From Our Village, We Empowered".

One of the reasons Kampung Marketer was established was that young people would not flock to find work in the city. According to the founder of Kampung Marketer, what would be a village without the youth who would be the successors to develop the village? One of the reasons why young people go to the city is that the income they receive in the village is lower than in the city. Therefore, Kampung Marketer can answer the challenges of this explanation. Kampung Marketer has 18 branches, then in 2020 was become 21 branches spread across the region, those all exist to absorb labor. Kampung Marketer also creates business opportunities for the 
community around the Kampung Marketer by creating restaurants, catering businesses, lodging, laundry, and so on so that it can increase economic growth It can be seen from the number of Kampung Marketer as shown in the image below:

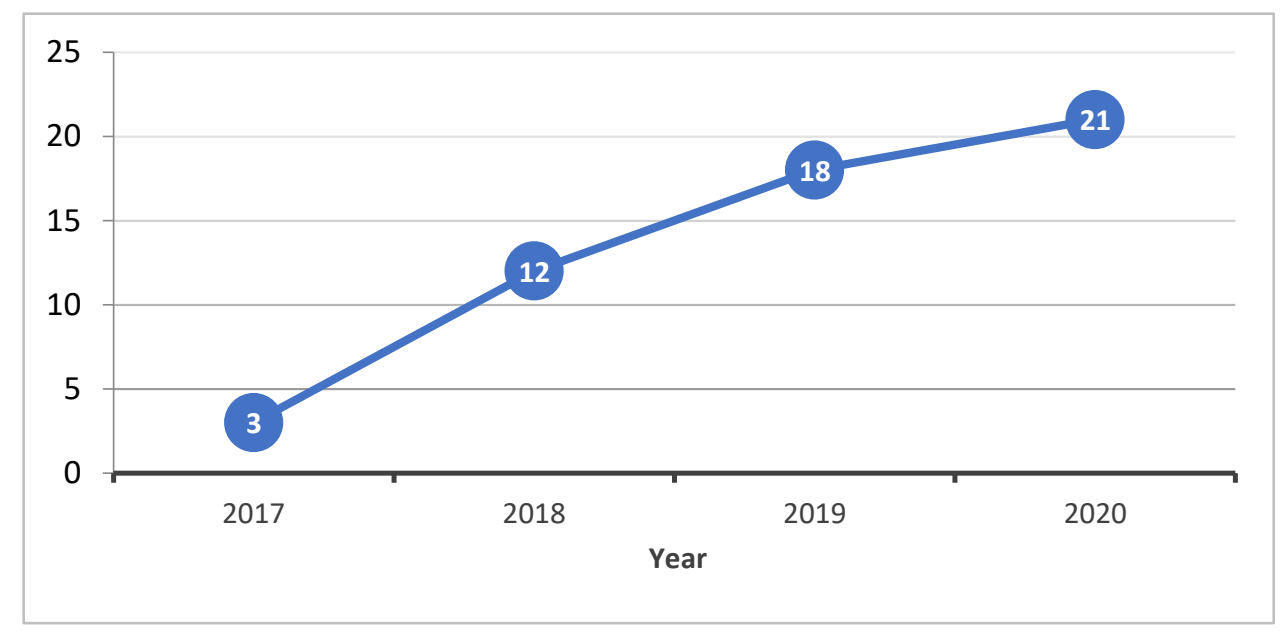

Figure 2. Number of branch offices in Kampung Marketer

Figure 2 shows that the number of branch offices in Kampung Marketer increases every year. With the increasing number of business branches, it is hoped to increase economic growth. Kampung Marketer also creates business opportunities for the community around the Kampung Marketer by creating restaurants, catering businesses, lodging, laundry, and increasing economic growth. Sari et al. (2020) stated that the development of entrepreneurship positively impacts the socio-economic conditions of the community. Figure 3 shows the average salary received by talent or members in the Kampung Marketer.

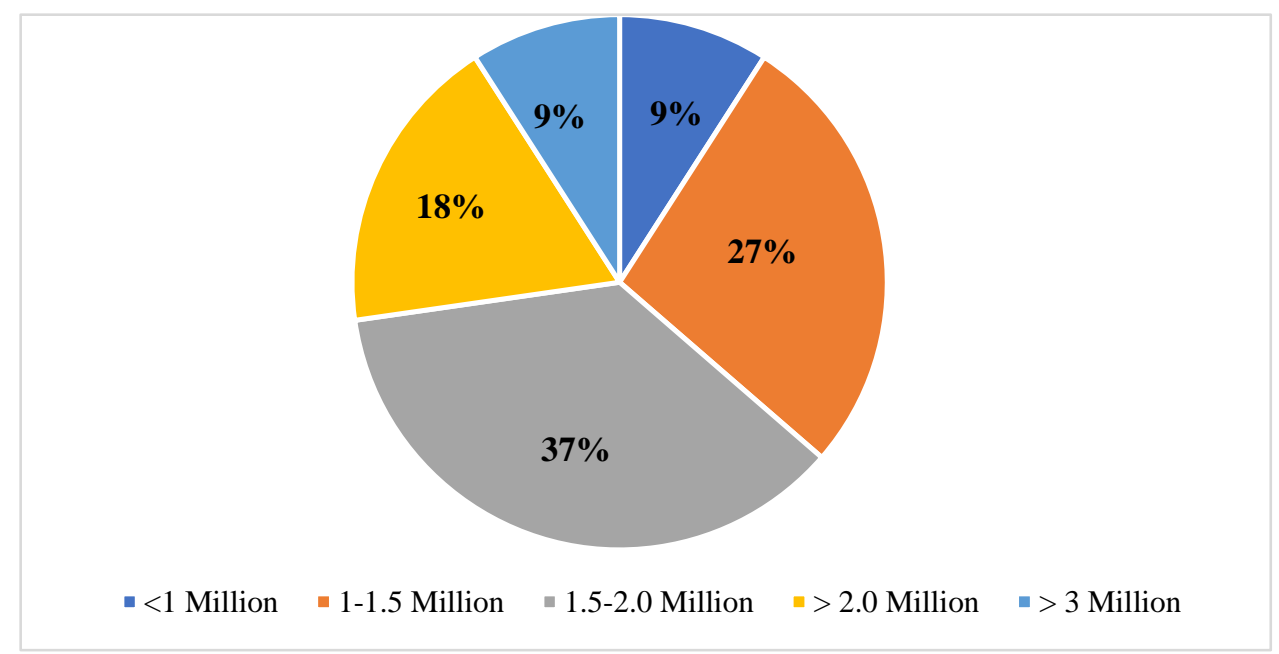

Figure 3. The salary range for talent or members of Kampung Marketer

Figure 3 shows that the salary range for talent or members of Kampung Marketer averages 1.5 - 2 Million, and there are 3 million with a total of $9 \%$ above the average district minimum wage. This shows economic growth with the presence of the role of digital technology in people-centered development. This proves that the 
existence of Kampung Marketer has a positive impact on the community. The income that each community has creates the economy of the citizens experience a dramatic increase if we compared to unemployment or farmers. This condition is in line with the research carried out by Murti et al. (2017) in Sari et al. (2020) about increasing the assessment of the people around Cavinton Hotels, and Tentrem Hotels that come from food stalls and shops due to the existence of the two hotels stated that the increase in income could improve the welfare of the community because considerable employment opportunities would reduce the unemployment rate of the surrounding community. This is in line with the research conducted by Safira et al. (2019), this opportunity to earn income with the help of digital technology.

Apart from being seen from the increase in the number of Kampung Marketer branches which have an impact on economic growth where the business is established, it can also be seen from the average salary received by talent or members who join the marketer village, and it can also be seen from the large amount of turnover generated from empowerment in the Kampung Marketer. In 2019, the total turnover was IDR 13 million, increasing to IDR 15 million in 2020. The increase in turnover shows economic growth, as in Sari et al.'s (2020) research.

Fulfilled the basic needs of the community and a better quality of life. Based on the increase in income received by empowered human resources in Kampung Marketer, Kampung Marketer had fulfilled the community's basic needs and improved the quality of life for the surrounding community. The existence of Kampung Marketer by conducting people-centered development through the use of digital indirectly fulfilled basic needs, one of which is the need for better education. As previously explained, the education level of the Marketer Village's human resources are on average Junior High School and Senior High School education, Bachelor's Degree is still minor. The increase in income received is agreed with the high enthusiasm of the younger generation who want to continue their higher education by setting aside their earned income. Along with the parents involved in activities formed by Kampung Marketer, they could finance their children's education and even buy houses and land.

Besides the younger generation, the elderly who did not have technological skills were also concerned and empowered by establishing a business called "Saung Makaryo". They were trained to produce goods in their respective homes, and Kampung Marketer marketed the products. One of the products is sandals. Parents can work while carrying out their obligations as housewives because everything is done at home. The existence of Kampung Marketer affected changes in the socio-economic conditions of the surrounding community. For the better, changes in the economy have a positive correlation, although they have not spread evenly. Kampung Marketer itself accepts everyone who wants to learn seriously, is willing to be given digital technology training, has the kindness to build a commitment, and is consistently willing to be empowered regardless of education level or age level.

Based on the income theory proposed by Soeratmo (2003), family income is each family member who works at work age for the welfare of his family. Family members such as wives and children contribute to various activities both in housework and earning a living. The income of the family of the community empowered by Kampung Marketer was obtained from the husband or wife who worked in Kampung Marketer and obtained income from other businesses. This is in line with the research conducted by Hazel Maxwell et al. (2019), which revealed that empowerment through digital could contribute to the surrounding environment. 


\section{CONCLUSIONS AND RECOMMENDATIONS}

\section{Conclusions}

The Kampung Marketer is a forum for community empowerment through digital marketing technology. The use of technology in the Kampung Marketer is reflected through the programs carried out in the Kampung Marketer.

Kampung Marketer provides education and training to residents who enter the Kampung Marketer to become skilled human resources in the field of digital technology in terms of online marketing. Education and training related to digital marketing knowledge, product research, copywriting, Instagram and Facebook ads, cash on delivery transactions, team building and KPI (Key Performance Indicators), and financial literacy. Some of the skills taught in Kampung Marketer will shape him into an advertiser, social media admin, content writer, etc.

The existence of Kampung Marketer is as part of community development efforts through the people-centered development paradigm approach by evaluating using the basic needs approach. The basic needs approach is a measurement of the progress of community development as indicated by an approach from the theory of basic needs that emphasizes 3 (three) development goals, including created job opportunities, increased economic growth, and fulfilling the basic needs of the community or a better quality of life.

The success of Kampung Marketer in utilizing technology as an effort for community development with empowerment is agreed with the basic needs approach. This could be seen in the creation of job opportunities is that every year there is an average increase of $25 \%$ for the number of talents who joined Kampung Marketer. The increase in economic growth evidence another success of Kampung Marketer. Apart from the amount of income and turnover distributed of 1.3 billion per month, it could also be seen from the many branches of Kampung Marketer spread across the Regency where Kampung Marketer was established. Finally, the fulfillment of basic needs in the education sector with the increasing number of human resources who continue their education to a higher level.

\section{Recommendations}

The implication of this research showed the importance of creative digital done by Kampung Marketer to build a community by empowering it to improve a better economic life for the younger generation and the surrounding community. For the achievements of Kampung Marketer, following previous research, people-centered development through empowerment by utilizing technology in the 4.0 era has a positive impact, and there is a need for sustainability and attention from the government so that later it can be further developed and collaborated with government programs.

\section{REFERENCES}

Bogdan, R. \& Taylor, S. (1975). Metodologi Penelitian Kualitatif. Bandung: Remadja Karya.

Brokensha, D. \& Hodge, P. (1969). Community Development: An Intrepretation. San Fransisco, CA: Chandler.

Chasanah, U. (2021). Implementasi Social Entrepreneurship Dalam Pemberdayaan Masyarakat. [Thesis]. Purwokerto: Universitas Islam Negeri Prof. K.H. Saifuddin Zuhri.

Christenson, J. \& Robinson. (1980). Community Development in America. Ames: The Lowa State University. 
Dunham, A. (1958). Community Welfare Organization (Principles and Practice). Third Printing. New York: Thomas Y. Crowell Company

Fianingsih. (2020). Pemberdayaan Masyarakat Melalui Kampung Marketer. [Thesis]. Purwokerto: Universitas Islam Negeri Prof. K.H. Saifuddin Zuhri

Iyengar, V., Pillai, S., Pednekar, J., \& Abhyankar, M. (2017). Enablers for digital empowerment in technology using interpretive structural modeling (ISM) and MICMAC analysis. Int J Appl Bus Econ Res, 15(2), 161-176.

Korten, D., \& Klauss, R. (1984). People Centered Development: Contribution Toward Theory and Planning Framework. Connecticut: Kumarian Press.Inc.

Maxwell, H., O'Shea, M., Stronach, M. \& Pearce, S.. (2019). Empowerment through digital health trackers: an exploration of Indigenous Australian women and physical activity in leisure settings. Annals of Leisure Research, 24(1), 150-167.

Moleong, J.L. (2012). Metodologi Penelitian Kualitatif. Bandung: PT. Remaja Rosdakarya.

Muafani, M. (2021). Pemanfaatan Teknologi Informasi Di Tengah Pandemi Covid-19 Dalam Pemberdayaan Masyarakat. Jurnal Penelitian Dan Pengabdian Kepada Masyarakat UNSIQ, 8(2), 134-139.

Nasdian, F. T. (2015). Pengembangan Masyarakat. Jakarta: Yayasan Obor Indonesia.

Sari, P. N., Lianingsih, S., \& Sari, Y. S. (2020). How Does Social Entrepreneurship Affect Socio Economic Condition of the Society? KnE Social Sciences, 4(6), 381-396.

Safira, M. R., \& Irwansyah, I. (2019). The Social Humanism Factor in Digital Empowerment in Indonesia Study on Kampung Blogger, Menowo Village, Central Java: Study on Kampung Blogger, Menowo Village, Central Java. In 2019 International Conference on Advanced Computer Science and Information Systems (ICACSIS) (pp. 409-416).

Simamora, C. M. (2020). Inklusivitas Ekonomi Digital Di Indonesia: Perspektif Gender Dan Penciptaan Lapangan Kerja. Journal of Trade Develpment and Studies, 4(2), 39-53

Sjahrir, K. (1988). Pembangunan Berdimensi Kerakyatan. Jakarta: Yayasan Obor Indonesia.

Soedjatmoko. (1979). Policy Implication of Basic Needs Approach. United Nations Centre for Regional Development

Suaedi, F., \& Hariani, N. J. (2018). Community Empowerment Through Digital Maternal and Neonatal Care Service in Indonesia. In Proceedings of the 4th International Conference on Contemporary Social and Political Affairs (ICoCSPA 2018), pages 153-156.

Sugiyono. (2011). Metode Penelitian Kuantitatif dan R\&D. Jakarta: Alfabeta.

Suherman. (2017). Pembangunan Masyarakat Melalui Pendekatan Pemberdayaan (People Centered Development). Journal of Region Public Administration (JRPA), 2(1), 1-5

Soeratmo. (2003). Ekonomi Mikro Pengantar. Yagyakarta: (UPP) AMP YKPN

Zimmerman, M. A. (2000). Empowerment theory. In Handbook of community psychology (pp. 43-63). Boston, MA. : Springer.

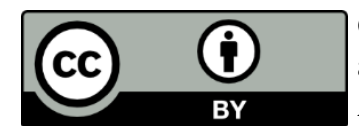

(C) 2022 by the authors. Licensee JPPD, Indonesia. This article is an open-access article distributed under the terms and conditions of the Creative Commons Attribution (CC BY) license (http://creativecommons.org/licenses/by/4.0/). 